\title{
Medication Adherence and Affecting Factors among Type Two Diabetic Patients, Attending Al-Daraga Health Center, Wad Madani Al Kubra, Gezira State, Sudan, (2020)
}

\author{
Author: Dr. Rasha Kamal Eltayeb Bashir * \\ SEHA Ambulatory Healthcare Services, United Arab Emirates \\ Co-Author: Dr. Imad Eldin Eljack Suleiman Ahmed
}

Ph.D. Department of family and community medicine University of Gezira, Sudan

\section{Co-Author: Dr. Tasabeh Mustafa Eltayb Ali}

Head Department of family and community medicine, University of Gezira, Sudan

\section{Email: Rashakamal23@hotmail.com *}

\begin{abstract}
:
Type II diabetes mellitus and its complication are becoming more prevalent in Sudan. The most important predictor of reduction of morbidity and mortality due to diabetes complication is the level of glycemic control achieved. In Sudan diabetes mellitus (DM) is common public health problem, in 2017 about 12\% developed serious complications. This study aimed to identify the general characteristics of type II diabetic patients, relevant diabetic characteristics duration, treatment, control and complications. Also to determine level of adherence, and reason behind non adherence medications. A cross-sectional study of randomly selected 360 patients of type II diabetic patient that attend at Al-Daraga Health Center, Wad Madani,Al Kubra locality, Gezira state ,during period from September October 2020, found that there's statistically significant showed the relation between marital status, socioeconomic status, level of education,
\end{abstract}


Occupation and factors affect adherence in taken medications at ( $\mathrm{p}$ value less than 0.05) also There's significant relation between causes with patients not adhered to used medications ( $\mathrm{p}$ value 0.000 ), The socioeconomic status contributed factors in diabetes mellitus complication because the low income level about 213(59.2\%). Type II diabetic patients was associated with higher glycated hemoglobin seen among younger age groups. It is also showing the important of Group discussion with the patients to increase awareness of adhering to treatment plan. This study will be helpful in providing evidence regarding the importance of adherence should be emphasized and empowered within the diabetic population.

Keywords: Medication, Affecting Factors, Diabetic Patients, Al-Daraga Health Center, Sudan

\section{1- Introduction}

Diabetes mellitus is the most common endocrine disease worldwide; it is a serious major health problem. Currently, 285 million were affected, and the projection for the year 2030 is 438 million (Forouhi and Wareham, 2014)

According to the World Health Organization estimation, half-million Sudanese people were affected by diabetes mellitus in the year 2000 and this trend is expected to reach one million in the year 2030 (Zheng et al., 2018)

Non-adherent to the prescribed medications and non-compliance for lifestyle changes are principal factors in poor glycemic control and micro vascular complications including neuropathy, nephropathy and retinopathy with deleterious consequences on the patients and the community as a whole. (Naqvi et al., 2019).

Glycemic control in type 2 diabetes is essential to prevent long-term micro- and macro vascular complications. (Care, 2014)

A number of factors other than glycated hemoglobin (HbA1c) level will influence treatment regimens, 
And practice guidelines emphasize the need for concomitant treatment of other cardiovascular risk factors, such as arterial hypertension $(\geq 140 / 80 \mathrm{mmHg})$ and dyslipidemia [low density lipoprotein $(\mathrm{LDL})>2.6 \mathrm{mmol} / \mathrm{L}$;

triglycerides $>1.7 \mathrm{mmol} / \mathrm{L}]$. As a consequence, many patients with type 2 diabetes are taking a complex regimen of drugs. (Osterberg and Blaschke, 2005)

Drugs and lifestyle changes to control type 2 diabetes and associated conditions can only be effective through adherence to the overall prescribed regimen. (Osterberg and Blaschke, 2005)

The World Health Organization (WHO) has shown that adherence to long term therapy and for lifestyle modifications for chronic illnesses in developed countries averages only around 50\%. Adherence rates are usually reduced for patients with chronic conditions than those with acute conditions; this is associated with the long-term nature of chronic diseases because the decline in adherence is most rapid after the first 6 months of therapy (AlQarni et al., 2019)

Furthermore, medication adherence is an important determinant of outcomes in patients with chronic diseases such as diabetes mellitus. For those with diabetes, adherence to medications is associated with better control of intermediate risk factors, lower odds of hospitalization, lower health care costs, and lower mortality. Estimates of rates of adherence to diabetes medications vary widely depending on the population studied and how adherence is defined. (AlQarni et al., 2019)

So, throughout this context, this study aimed to evaluate medication adherence and associated factors among type two diabetic patients, attending

Al-Daraga Health Center, Wad Madani AlKubra, Gezira state, Sudan, 2020. By documenting the adherence pattern of type II diabetic patients in this area, it is hoped that this study will form the basis for further investigations exploring patient behavior towards adherence among type two diabetic patients. 


\subsection{Problem Statement}

Nearly 415 million people globally have diabetes, with $75 \%$ living in low and middleincome countries. In India, about 70 million people have diabetes, and the number is projected to rise to 125 million by 2040. (Forouhi and Wareham, 2014)

In Sudan, diabetes mellitus is becoming a common public health problem. (Omar et al., 2019)Last study done in Africa by Ms Omar Musa in 2017 (the prevalence of DM in Africa in 2017 was 3.3\% and Sudan was among the countries that had a prevalence of DM among 12\%. (Awadalla et al., 2017)The issue of adherence to medication is important for chronic illnesses such as type II diabetes mellitus (DM) as it is characterized by fluctuating blood glucose levels. This fluctuation can either lead to hyperglycemia, i.e., a condition in which there is an elevation in serum level of blood glucose and vice versa, i.e., hypoglycemia. (Naqvi et al., 2019)

Both are detrimental for a patient's health and well-being. Studies report that uncontrolled DM may lead to macro and micro vascular complications and co morbidities such as hypertension, kidney disorders, retinopathy and in rare cases, Parkinsonism. Hence, proper management of the disease and close adherence for medications is helpful in attainment of a healthy lifestyle with better management outcome. (Care, 2014)

\subsection{Justification}

Many studies showed that good knowledge and practice regarding the importance of adherence for diabetic medications will reduce the risk of the occurrence of these complications and ultimately morbidity and mortality.

According to the best knowledge of the researcher, there is no available of published research work that aimed to assess knowledge, attitude and practice of diabetes type II patients toward adherence toward diabetic management, health centers, in Wad Medani Al Kubra Locality, Gezira state, Sudan, within the few previous years. 
Within this perspective, this study may help to offer valuable rationalized information for variety of beneficiaries such as the patients themselves and their families.

Moreover, it is of important for family physicians, and relevant medical staff; in order to be more critical in investigation to be more precise in overall level of adherence regarding this important issue among type 2 diabetic patients in Sudan.

\section{3 objectives}

\subsubsection{General objective}

To assess medication adherence and associated factors among type II diabetic patients, attending Al-Daraga Health Center, Wad Madani Al Kubra, Gezira state, Sudan, 2020

\subsubsection{Specific objectives}

1. To determine the level adherence to diabetes medication among type II diabetic patients

2. To identify relevant diabetic characteristics such as duration, type of treatment, family history, presence of diabetes complications, and the status of diabetic control

3. To determine the reason behind the non-adherence for diabetes medications among type II diabetic patients

4. To determine the possible relation between factors (demographical/diabetes related) that may have associated with their overall level of adherence toward diabetes medication and life style changes

\section{Literatures Review}

Management adherence can be defined as taking medications and life style modifications as advised and prescribed by healthcare professionals for the stated duration. (Naqvi et al., 2019)

It is one of the challenging global issues; non-adherence to medication results in active disease progression and increased treatment costs.(Osterberg and Blaschke, 2005) 
According to the literature, almost $50 \%$ of the patients suffering from chronic illnesses - such as diabetes - do not adhere to their medication regimen, not attempted to changes their required lifestyle relevant issues, and half of them indulge in non-adherence after a year of treatment co morbidities that may increase the frequency of hospital admissions, emergency visits and direct treatment costs. (AIQarni et al., 2019)

These direct costs, depending upon the healthcare sector of a country, may either be borne by the health sector or in some cases the patient. (Osterberg and Blaschke, 2005), (AlQarni et al., 2019)

In Sudan, Hyder Osman et al evaluated the adherence to anti-diabetic medications among type 2 diabetic patients in a Sudanese Um dorman outpatient clinic. The study results summarized the following: participants ( $70.6 \%$ women), their mean age was (59.62 \pm 9.91$)$ years and nearly $60.8 \%$ were housewives, their glycated hemoglobin (mean \pm SD) was about $10.16 \pm 3.14,37.3 \%$, it implies that the patients were nonadherent to medications. In addition, other groups of patients with medication but nonadherence were younger ones $(55.94 \pm 9.94$ vs. $61.81 \pm 9.36, \mathrm{P}=0.04)$ and had shown inadequate glycemic control ( $11.33 \pm 3.05 v s$. $9.47 \pm 3.04, \mathrm{P}=0.04)$, however, this group of patients has reported more drug-related side effects (57.8\% vs. $28.1 \%$ ) because they were taking more drugs compared to their counterparts( $\mathrm{F}=4.115, \mathrm{P}=0.047)$.

The present study found no statistically significant differences in the following factors such as sex, occupation, education level, financial problems and insulin use. In conclusion, the study revealed that adherence to ant diabetic medications was suboptimal among Sudanese type 2 diabetic patients and was associated with higher glycated hemoglobin seen among younger age groups. Besides the above, overdosing of medications and their side effects were evident. (Mirghani, 2019)

In Nigeria, Yusuff KB et al assessed the adherence to anti-diabetic drug therapy and self-management practices/life styles among type-2 diabetics. Oral Hypoglycemic Agents (OHA) were prescribed for 86\% (171) of cohorts while insulin and OHA was prescribed in $14 \%$ (29). 
About $70.8 \%$ (121) of patients on OHA were on combination therapy. The most frequently prescribed OHA combination was glibenclamide and metformin (95.8\%). Glibenclamide was prescribed as twice daily regimen in $69 \%$ of cohorts. The most frequently documented side effect was hypoglycemia (60.3\%). Only 44\% (88) of cohorts had adequate glycemic control; of these, 93\% (82) were adjudged adherent with prescribed anti-diabetic drugs.

Interviews with the structured ASMMT revealed that 59\% of patients were nonadherent with the previous anti-diabetic drugs due to lack of finance (51.7\%); side effects (34.5\%); perceived inefficacy of prescribed anti-diabetic drugs leading to selfmedication with local herbs (13.8\%). Only $20 \%$ of non-adherent patients claimed disclosure to physicians during consultation. The identified factors for non-disclosure were lack of privacy during consultation (58\%); and short consultation time (42\%). The knowledge and practice of critical components of diabetes self-management behaviors were generally low among the cohort studied. However, it was significantly higher among patient judged adherent with their prescribed anti-diabetic medications ( $\mathrm{P}<$ 0.05). They concluded that majority of patients with type 2 diabetes in an ambulatory tertiary care setting in Nigeria are managed with OHA combinations, mainly Glibenclamide and Metformin. While the current prescribing strategy achieved glycemic control in about one third of patients, majority are still not meeting the recommended blood glucose targets due to poor adherence with prescribed drug regimen, and poor knowledge and practice of successful self management. (Yusuff et al., 2008)

In India, Saurav Basu et al addressed the adherence to self-care practices, glycemic status, treatment and lifestyle accommodations and influencing factors in diabetes patients. They revealed that mean age of the study subjects was $49.7 \pm 10.2$ years. A total of 201 men and 174 women were enrolled in the study. Three hundred nine $(88.4 \%)$ subjects were adherent to their intake of anti-diabetic medication. 
On binary logistic regression, education level below primary school completion and absence of hypertension co morbidity were found to be independent predictors of medication non-adherence. Socio cultural resistance was an important factor impeding outdoor exercise among younger women. Knowledge of diabetes in the study subjects was low with mean score of $3.1 \pm 2$ (maximum score $=10$ ). Suboptimal glycemic control was found in $259(69 \%)$ subjects which was significantly more likely in patients on Insulin therapy compared to those on Oral Hypoglycemic agents alone $(\mathrm{P}<0.006)$. They concluded that a large gap existed between self reported medication adherence and glycemic control. This suggests the need for enhanced physician focus for diabetic patient management (Basu et al., 2018)

In Spain, Luis-Emilio et al assessed the factors associated with adherence to medication in Patients with Type 2 Diabetes. They revealed that reasons for nonadherence are multifactorial and difficult to identify. They include age, information, perception and duration of disease, complexity of dosing regimen, polytherapy, psychological factors, safety, tolerability and cost. Various measures to increase patient satisfaction and increase adherence in type 2 diabetes have been investigated. These include reducing the complexity of therapy by fixed-dose combination pills and less frequent dosing regimens, using medications that are associated with fewer adverse events (hypoglycemia or weight gain), educational initiatives with improved patienthealthcare provider communication, reminder systems and social support to help reduce costs. In the current narrative review, factors that influence adherence to different therapies for type 2 diabetes are discussed, along with outcomes of poor adherence, the economic impact of non-adherence, and strategies aimed at improving adherence. (Garcia-Perez et al., 2013)

\section{Materials and Methods}

3.1 Study Design: Observational, descriptive analytical cross sectional facility based study. 
3.2 Study Area: The study was conducted in Al-Daraga Health Center. This center is located in Al-Daraga neighborhood, Wad Madani AlKubra locality, Gezira state, Sudan. The center offers basic preventive and curative services for population in the surrounding residential area.

\section{Al Daraga health center:}

- Affiliate to the health insurance fund

- Working days : provide service 6 days per week from 8 am to 8 pm

The center facilities:

Doctors (8 general practitioner 6 days per week, 1 surgeon and 1 internal medicine doctor one day /week) , laboratory, Dietitian, vaccination, midwife, Resuscitation room

- Number of patient /day : 200-250 patient (100 - 150 type 2 DM patient)

3.3 Study duration: The study was conducted within the period from September October 2020.

3.4 Study Population: The study covered adults with type II DM attended Al-Daraga Health Center, who fulfilled the following criteria:

\subsubsection{Inclusion Criteria}

- Adults 18 years in age or older

- Diagnosed with type II diabetes

- Attended Al-Daragar Health Center, within the study period

\subsubsection{Exclusion Criteria}

- Less than 18 years old

- Diagnosed with type 1 diabetes

- Sever ill patient

\subsection{Sample Size and Technique:}

Participants were selected through simple random sampling technique. 
the first patients who have inclusion criteria attended the health center was choosin, and wrot e the number of the patient then missed 2 patient, then selected number 4 , missed 2 patient, se lected number 7 , until reaching the total number of sample selected 360 participants accordi ng to formula :

\section{Equation 3: $\quad \mathbf{n}=\frac{\mathrm{N}}{1+\mathrm{N}(\mathrm{e})^{2}}$}

(Taro Yamane 1967)

- Where n: is the sample size

- $\quad \mathrm{N}$ : is the population size

- $\quad$ e : marginal errors $=0.05$

- Estimated population size $=150$ diabetic patients (daily) that equivalent to 3600 patients in one month's (the duration of data collection period - with 6 working days per week for four weeks).

- So, the calculated sample size can be adjusted through the following:

$\mathbf{n}=\mathbf{3 6 0 0} / \mathbf{1}+(\mathbf{3 6 0 0} \times \mathbf{0 . 0 0 2 5})=360$ participants $($ cases $)$ in the minimum throughout study period per day $360 / 24=15$ patient $/$ day

\subsection{Data Collection Tools:}

The data was collected via face-to-face interviews by trainees using comprehensive structured questionnaire, which contain 16 questions, close and open ended questions. The data collection tools covered variables, as 7 Demographical characteristics, 9 clinical assessment for diabetes characteristics, and level of adherence toward diabetes management. 


\subsection{Study Variables:}

Study variable can be classified as shown in the following table:

\begin{tabular}{|c|c|}
\hline Main Categories & Variable \\
\hline Independent & $\begin{array}{l}\text { Demographical data } \\
\text { - } \text { Age } \\
\text { - Gender } \\
\text { - Marital status } \\
\text { - Socioeconomic status } \\
\text { - Residence } \\
\text { - Education } \\
\text { - Occupation } \\
\text { Diabetes characteristics } \\
\text { - } \text { Family history } \\
\text { - } \text { Duration } \\
\text { - Drugs used for treatment } \\
\text { - Diagnosed with diabetes complications } \\
\text { - Physical activity }\end{array}$ \\
\hline Dependent & -Level of adherence toward DM medications \\
\hline Main Categories & Variable \\
\hline & -Reasons of non-adherence for DM medications \\
\hline
\end{tabular}

\subsection{Statistical Analysis and Presentation:}

- Data was entered and organized, using Statistical package for social science (SPSS) version 24.

- Descriptive statistics in term of frequency tables with percentages and graphs. Means and standard deviations was presented with relevant graphical representation for quantitative data.

- Bi-variable analysis to determine the relation between general demographical/diabetes related characteristics and the level of adherence toward 
diabetes management using Chi squared statistical test (for categorical variables) and paired t- test (quantitative variables) statistical tests. Used multiple regression (dependent and in dependent variable )

- P value of 0.05 or less is considered statistically significant.

- Data was represented after analysis in form of uni-variable tables, cross tabulation (bi variable tables), figures and narrative illustration.

\subsection{Ethical Considerations}

- Written ethical clearance and approval from Gazira University Ethical Committee, for conducting this research.

- Written permission was obtained from the administrative authority of Al-Daraga Health Center, Wad Madani Al Kubra, Gezira state, Sudan

- Research objectives explained to participant in clear simple words for the research purposes only. The privacy issues was intentionally considered.

- Written consent was obtained from all study participants.

\section{Results:}

In the study a total of 360 patient was included.

Table (4.1)

Distribution of selected sample according to demographic Characteristics among Type II Diabetic Patients $(\mathbf{n}=\mathbf{3 6 0})$.

\begin{tabular}{|l|c|c|}
\hline Age & Frequency & Percent \\
\hline $18-20$ years & 14 & 3.9 \\
\hline $20-30$ years & 22 & 6.1 \\
\hline $31-40$ years & 42 & 11.7 \\
\hline $41-50$ years & 84 & 23.3 \\
\hline More than 50 years & 198 & 55.0 \\
\hline Total & 360 & 100.0 \\
\hline
\end{tabular}


Academic Journal of Research and Scientific Publishing | Vol 3 | Issue 27

Publication Date: 5-7-2021 ISSN: 2706-6495

\begin{tabular}{|c|c|c|}
\hline \multicolumn{3}{|l|}{ Gander } \\
\hline & Frequency & Percent \\
\hline Male & 202 & 56.1 \\
\hline Female & 158 & 43.9 \\
\hline Total & 360 & 100.0 \\
\hline \multicolumn{3}{|l|}{ Marital Status } \\
\hline & Frequency & Percent \\
\hline Single & 40 & 11.1 \\
\hline Married & 209 & 58.1 \\
\hline Divorced & 24 & 6.7 \\
\hline Widowed & 87 & 24.2 \\
\hline Total & 360 & 100.0 \\
\hline \multicolumn{3}{|l|}{ Social Income status } \\
\hline & Frequency & Percent \\
\hline Low & 213 & 59.2 \\
\hline Middle & 136 & 37.8 \\
\hline High & 11 & 3.1 \\
\hline Total & 360 & 100.0 \\
\hline \multicolumn{3}{|l|}{ Residence } \\
\hline & Frequency & Percent \\
\hline Urban & 276 & 76.7 \\
\hline Rural & 84 & 23.3 \\
\hline Total & 360 & 100.0 \\
\hline \multicolumn{3}{|l|}{ Educational level } \\
\hline & Frequency & Percent \\
\hline Illiterate & 62 & 17.2 \\
\hline Primary & 121 & 33.6 \\
\hline Secondary & 141 & 39.2 \\
\hline University or above & 36 & 10.0 \\
\hline Total & 360 & 100.0 \\
\hline
\end{tabular}


Academic Journal of Research and Scientific Publishing | Vol 3 | Issue 27

Publication Date: 5-7-2021 ISSN: 2706-6495

\begin{tabular}{|l|c|c|}
\hline \multicolumn{2}{|l|}{ Occupation } & Frequency \\
\hline House wife & 148 & Percent \\
\hline Medical/health related field & 26 & 41.1 \\
\hline Unemployed & 34 & 7.2 \\
\hline Worker & 38 & 9.4 \\
\hline Teacher & 12 & 10.6 \\
\hline Retired & 59 & 3.3 \\
\hline Farmer & 9 & 16.4 \\
\hline Engineer & 8 & 2.5 \\
\hline Butcher & 7 & 2.2 \\
\hline Driver & 19 & 1.9 \\
\hline Total & 360 & 5.3 \\
\hline
\end{tabular}

Majority of participants male more than female by (12.2\%),age more than 50 years (55\%), married more than others about (58.8\%), low socioeconomic (59.2\%)more, urban more than rural by $(53.2 \%)$, in educational level the secondary school were more than others items (39.2\%), 10 items about occupation,house wife were more (41.1\%).

\section{Table (4.2)}

As the table shows Majority of participants had family history of DM and well controlled $\mathrm{dm}(63.6 \%-63.6 \%)$ respectively. It is evident that most of the participants had at least one complication of DM 74.2\% and the most common complication was cardiovascular disease $88.2 \%$ followed by Ocular disease was about $17 \%$.

$97.2 \%$ of the patient included in the study said that they received excellent consultation about the disease and its complication.

\begin{tabular}{|l|l|l|l|}
\hline & Yes & No & Total \\
\hline $\begin{array}{l}\text { Family History of } \\
\text { MD }\end{array}$ & $63.6 \%$ & 36.4 & $100 \%$ \\
\hline $\begin{array}{l}\text { Patients Control By } \\
\text { (HbA1c) }\end{array}$ & $68.6 \%$ & 31.4 & $100 \%$ \\
\hline
\end{tabular}


Academic Journal of Research and Scientific Publishing | Vol 3 | Issue 27

Publication Date: 5-7-2021 ISSN: 2706-6495

\begin{tabular}{|l|l|l|l|}
\hline $\begin{array}{l}\text { Complications } \\
\text { Diagnosed }\end{array}$ & $25,8 \%$ & $74,2 \%$ & $100 \%$ \\
\hline Health Insurance & $73.1 \%$ & $26.9 \%$ & $100 \%$ \\
\hline Had Consultation & $97.2 \%$ & $2.8 \%$ & $100 \%$ \\
\hline
\end{tabular}

Figure: (4.1) this figure shows duration of type 2 diabetes among participants.

The majority of participants arranged between 3-5 years in diabetic duration selected sample among AL Daraga Health Center Wad Madani AL Kubra Gezira state $(n=360)$.

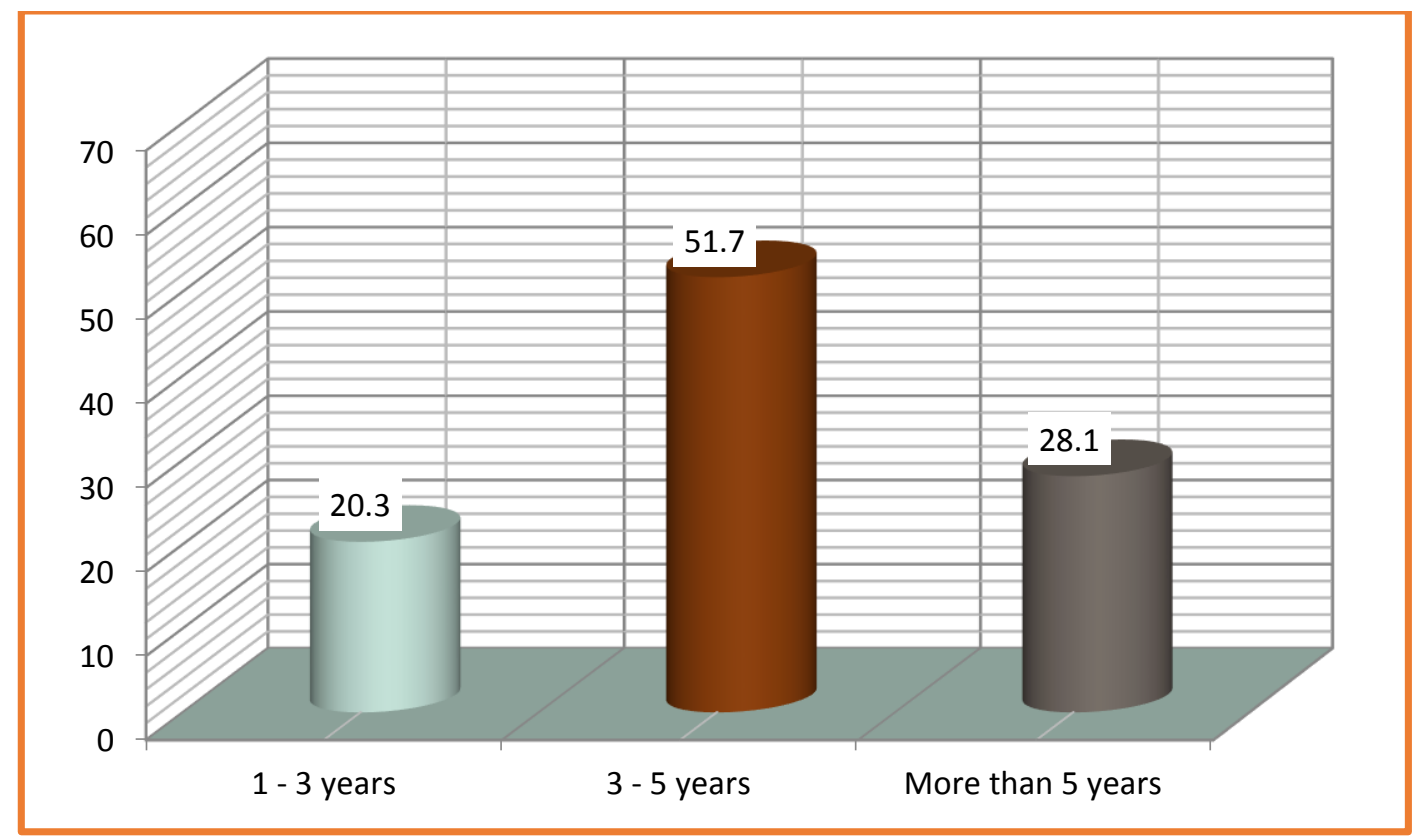

Figure: (4.2) Shows treatment of type 2 diabetic patients

The majority of participants were treated by insulin, among selected sample among AL Daraga Health Center Wad Madani AL Kubra Gezira state (n=360). 
Academic Journal of Research and Scientific Publishing | Vol 3 | Issue 27

Publication Date: 5-7-20. ISSN: 2706-6495

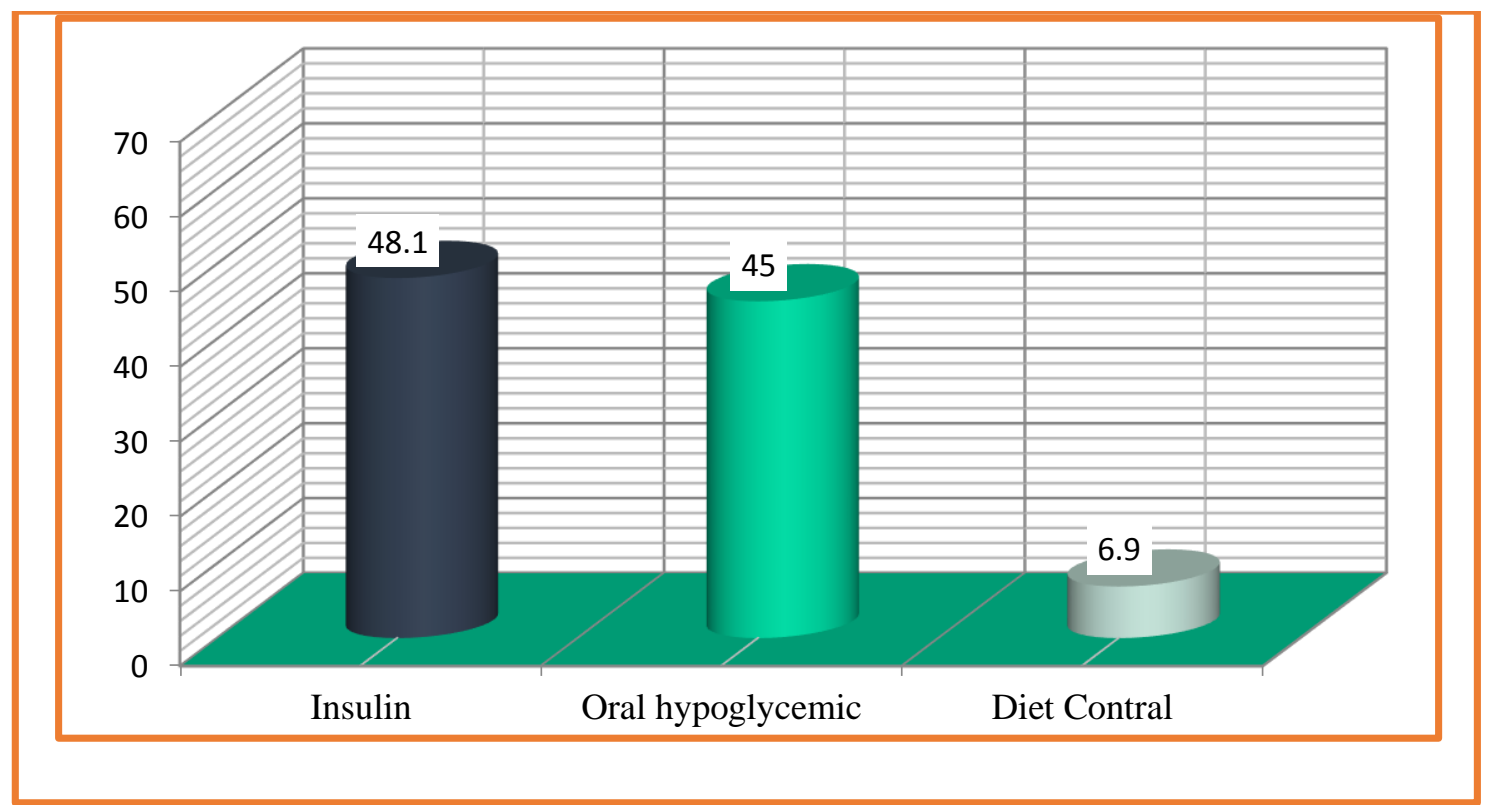

Figure: (4.3) this figure explained adherence management plan.

The majority of participants have poor Adherence to management according to sample selected among AL Daraga Health Center Wad Madani AL Kubra Gezira state $(\mathrm{n}=360)$.

Adherence:

Good adherence: taking medication regularly and follow management plan

Average adherence: taking medication and follow management plan irregularly

Poor adherence: Did not taking medication and did not follow management plan 
Academic Journal of Research and Scientific Publishing | Vol 3 | Issue 27

Publication Date: 5-7-20. ISSN: 2706-6495

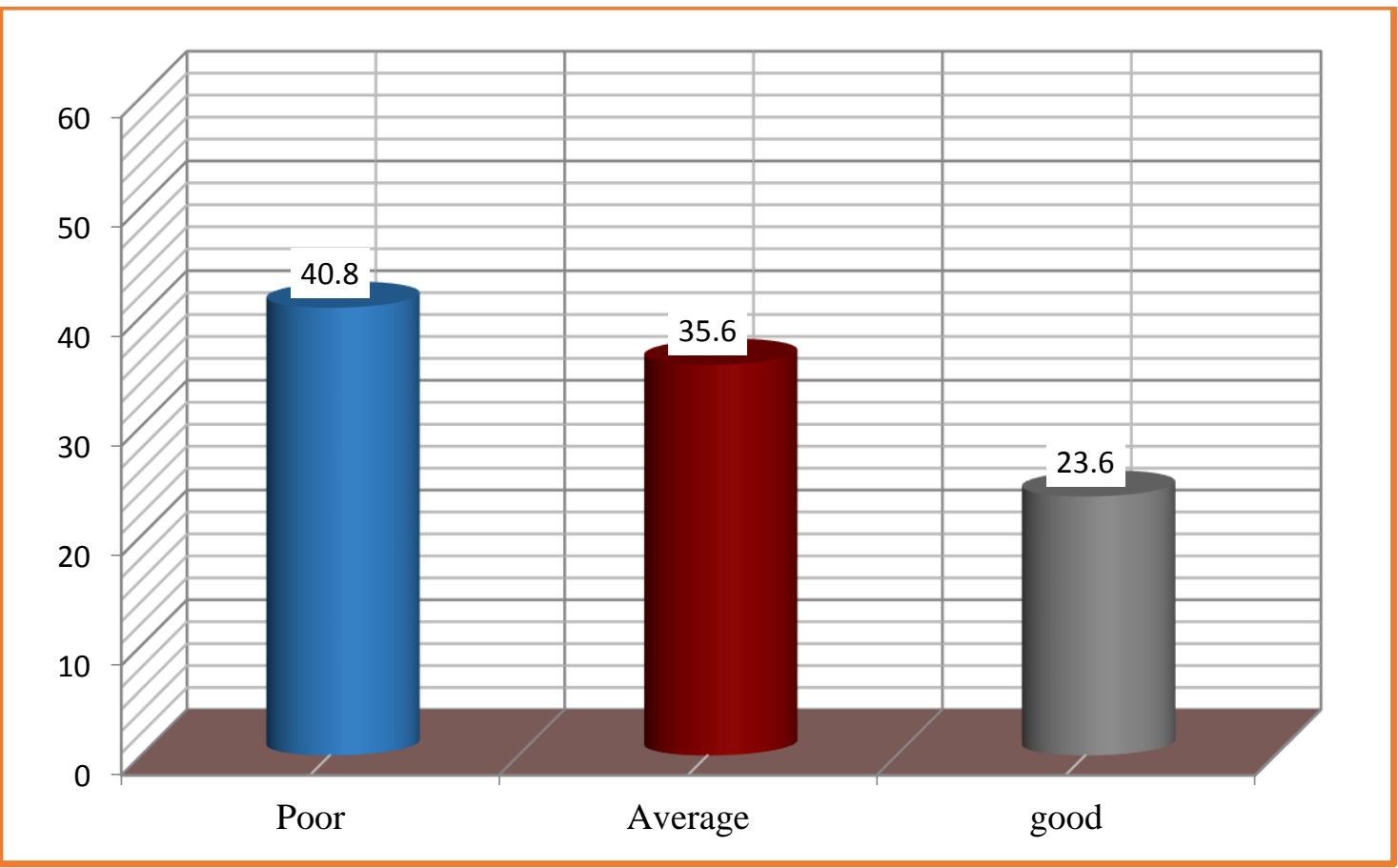

Table (4.3)

This table explained Causes that make participants not to adhere for using medications. The majority said no noticeable improved (45.3\%), Hard to be taken daily (30.35), Fear of complications (36.6\%) and Lack of knowledge about importance $(24,4 \%)$. (n=360).

\begin{tabular}{|l|c|c|}
\hline $\begin{array}{l}\text { Causes not to adhered medications } \\
\text { used }\end{array}$ & Frequency & Percentage \\
\hline Did not prescribed & 4 & $1 \%$ \\
\hline Hard to be taken daily for ever & 109 & $30,3 \%$ \\
\hline Fear of complications & 88 & $36,6 \%$ \\
\hline $\begin{array}{l}\text { Lack of knowledge about importance } \\
\text { of adherence to medication }\end{array}$ & 81 & $24,4 \%$ \\
\hline Expensive & 86 & $23,9 \%$ \\
\hline Not available at pharmacy & 163 & $45,3 \%$ \\
\hline No noticeable improvement & & \\
\hline
\end{tabular}


Academic Journal of Research and Scientific Publishing | Vol 3 | Issue 27

Publication Date: 5-7-20. ISSN: 2706-6495

No health insurance

47

$13,1 \%$

Table (4.5)

Compare Correlations of sociodemographaic characteristic with medications adherence:

\begin{tabular}{|c|c|c|c|c|c|c|c|c|c|}
\hline & & Age & $\begin{array}{c}\text { Gande } \\
\quad \mathbf{r}\end{array}$ & $\begin{array}{l}\text { Marita } \\
\text { I Status }\end{array}$ & $\begin{array}{c}\text { Social } \\
\text { Incom } \\
\text { e } \\
\end{array}$ & $\begin{array}{l}\text { Residenc } \\
\text { e }\end{array}$ & $\begin{array}{c}\text { Educationa } \\
\text { I } \\
\text { level } \\
\end{array}$ & $\begin{array}{c}\text { Occupatio } \\
\text { n }\end{array}$ & $\begin{array}{c}\text { Level of } \\
\text { adherenc } \\
\mathrm{e} \text { in taken }\end{array}$ \\
\hline \multirow{3}{*}{ Age } & $\begin{array}{c}\text { Pearson } \\
\text { Correlatio } \\
\mathbf{n}\end{array}$ & 1 & .103 & $.441^{* *}$ & $.133^{*}$ & .081 & $-.199^{* *}$ & -.062 & .039 \\
\hline & $\begin{array}{c}\text { Sig. (2- } \\
\text { tailed) }\end{array}$ & & .052 & .000 & .012 & .124 & .000 & .239 & .465 \\
\hline & $\mathbf{N}$ & 360 & 360 & 360 & 360 & 360 & 360 & 360 & 360 \\
\hline \multirow{3}{*}{ Gander } & $\begin{array}{c}\text { Pearson } \\
\text { Correlatio } \\
\mathbf{n}\end{array}$ & .103 & 1 & $.245^{* *}$ & -.064 & -.091 & $-.380^{* *}$ & -.045 & -.020 \\
\hline & $\begin{array}{c}\text { Sig. (2- } \\
\text { tailed) }\end{array}$ & .052 & & .000 & .225 & .085 & .000 & .399 & .707 \\
\hline & $\mathbf{N}$ & 360 & 360 & 360 & 360 & 360 & 360 & 360 & 360 \\
\hline \multirow{3}{*}{$\begin{array}{c}\text { Marital } \\
\text { Status }\end{array}$} & $\begin{array}{c}\text { Pearson } \\
\text { Correlatio } \\
\mathbf{n} \\
\end{array}$ & $.441^{* *}$ & $.245^{* *}$ & 1 & $.106^{*}$ & .095 & $-.104^{*}$ & $.132^{*}$ & $.230^{* *}$ \\
\hline & $\begin{array}{c}\text { Sig. (2- } \\
\text { tailed) }\end{array}$ & .000 & .000 & & .044 & .071 & .050 & .012 & .000 \\
\hline & $\mathbf{N}$ & 360 & 360 & 360 & 360 & 360 & 360 & 360 & 360 \\
\hline \multirow{3}{*}{$\begin{array}{l}\text { Social } \\
\text { Income }\end{array}$} & $\begin{array}{c}\text { Pearson } \\
\text { Correlatio } \\
\mathbf{n} \\
\end{array}$ & $.133^{*}$ & -.064 & $.106^{*}$ & 1 & $.132^{*}$ & $.185^{* *}$ & -.003 & $.180^{* * *}$ \\
\hline & $\begin{array}{l}\text { Sig. (2- } \\
\text { tailed) }\end{array}$ & .012 & .225 & .044 & & .012 & .000 & .952 & .001 \\
\hline & $\mathbf{N}$ & 360 & 360 & 360 & 360 & 360 & 360 & 360 & 360 \\
\hline Residence & $\begin{array}{c}\text { Pearson } \\
\text { Correlatio } \\
\mathbf{n}\end{array}$ & .081 & -.091 & .095 & $.132^{*}$ & 1 & .094 & .019 & .088 \\
\hline
\end{tabular}


Academic Journal of Research and Scientific Publishing | Vol 3 | Issue 27

Publication Date: 5-7-20. ISSN: 2706-6495

\begin{tabular}{|c|c|c|c|c|c|c|c|c|c|}
\hline & $\begin{array}{l}\text { Sig. (2- } \\
\text { tailed) }\end{array}$ & .124 & .085 & .071 & .012 & & .073 & .723 & .097 \\
\hline & $\mathbf{N}$ & 360 & 360 & 360 & 360 & 360 & 360 & 360 & 360 \\
\hline \multirow{3}{*}{$\begin{array}{c}\text { Educationa } \\
\text { I level }\end{array}$} & $\begin{array}{c}\text { Pearson } \\
\text { Correlatio } \\
\mathbf{n}\end{array}$ & $\begin{array}{c}- \\
.199^{*} \\
*\end{array}$ & $.380^{* * *}$ & $-.104^{*}$ & $.185^{* *}$ & .094 & 1 & $.166^{* *}$ & $.327^{\text {*** }}$ \\
\hline & $\begin{array}{c}\text { Sig. (2- } \\
\text { tailed) }\end{array}$ & .000 & .000 & .050 & .000 & .073 & & .002 & .000 \\
\hline & $\mathbf{N}$ & 360 & 360 & 360 & 360 & 360 & 360 & 360 & 360 \\
\hline \multirow{3}{*}{ Occupation } & $\begin{array}{c}\text { Pearson } \\
\text { Correlatio } \\
\text { n }\end{array}$ & -.062 & -.045 & $.132^{*}$ & -.003 & .019 & $.166^{* *}$ & 1 & $.265^{* *}$ \\
\hline & $\begin{array}{c}\text { Sig. }(2- \\
\text { tailed })\end{array}$ & .239 & .399 & .012 & .952 & .723 & .002 & & .000 \\
\hline & $\mathbf{N}$ & 360 & 360 & 360 & 360 & 360 & 360 & 360 & 360 \\
\hline \multirow{3}{*}{$\begin{array}{l}\text { level of } \\
\text { adherence } \\
\text { in taken }\end{array}$} & $\begin{array}{c}\text { Pearson } \\
\text { Correlatio } \\
\mathbf{n} \\
\end{array}$ & .039 & -.020 & $.230^{* *}$ & $.180^{* *}$ & .088 & $.327^{* * *}$ & $.265^{* *}$ & 1 \\
\hline & $\begin{array}{c}\text { Sig. (2- } \\
\text { tailed) }\end{array}$ & .465 & .707 & .000 & .001 & .097 & .000 & .000 & \\
\hline & $\mathbf{N}$ & 360 & 360 & 360 & 360 & 360 & 360 & 360 & 360 \\
\hline
\end{tabular}

There is significant Correlation between sociodemographic characteristic and adherence in taken medications in marital status $(\mathrm{P}=0.00)$, social income $(\mathrm{P}=0.001)$, Educational level $(\mathrm{P}=0.000)$, and Occupation $(\mathrm{P}=0.000)$.

But unsignificant in age $(\mathrm{P}=0.465)$, gander $(\mathrm{P}=0.707)$, and residence $(0.097)$.

Table (4.6)

Used multiple regression: Compare between sociodemographic characteristic and adherence.

\begin{tabular}{|c|c|c|c|c|c|c|}
\hline \multirow{2}{*}{\multicolumn{2}{|c|}{ Model }} & \multicolumn{2}{|c|}{$\begin{array}{l}\text { Unstandardized } \\
\text { Coefficients }\end{array}$} & \multirow{2}{*}{\begin{tabular}{|c|}
$\begin{array}{c}\text { Standardized } \\
\text { Coefficients }\end{array}$ \\
Beta
\end{tabular}} & \multirow[b]{2}{*}{$\mathrm{T}$} & \multirow[b]{2}{*}{ Sig. } \\
\hline & & B & Std. Error & & & \\
\hline 1 & (Constant) & .120 & .270 & & .447 & .655 \\
\hline
\end{tabular}


Academic Journal of Research and Scientific Publishing | Vol 3 | Issue 27

Publication Date: 5-7-20. ISSN: 2706-6495

\begin{tabular}{|l|r|r|r|r|r|} 
Gander & .109 & .083 & .069 & 1.317 & .189 \\
\hline Marital Status & .167 & .044 & .208 & 3.780 & .000 \\
\hline Social Income & .141 & .069 & .100 & 2.041 & .042 \\
\hline Residence & .050 & .089 & .027 & .561 & .575 \\
\hline Educational level & .286 & .047 & .323 & 6.045 & .000 \\
\hline Occupation & .054 & .014 & .187 & 3.841 & .000 \\
\hline Age & .000 & .038 & .000 & .004 & .997 \\
\hline
\end{tabular}

Coefficients between sociodemographic characteristic with adherence by used multiple regression.

There is significant in Marital Status, Social Income, Educational level and Occupation at sequences ( $\mathrm{p}$ value $0.00,0.04,0.00$ and 0.00 ) with adherence in taken medications. While unsignificant in age, gander, and residence at sequences ( $\mathrm{P}$ value $0.189,0.575$, and 0.997).

Table (4.7)

Compared Correlations of factors with medications adherence:

\begin{tabular}{|c|c|c|c|c|c|c|}
\hline \multicolumn{7}{|c|}{ Correlations } \\
\hline & & $\begin{array}{l}\text { Diabetes } \\
\text { duration }\end{array}$ & $\begin{array}{l}\text { Treatment } \\
\text { The }\end{array}$ & $\begin{array}{l}\text { Health } \\
\text { insurance }\end{array}$ & $\begin{array}{l}\text { Doctor tell you about an } \\
\text { importance of } \\
\text { adherence }\end{array}$ & $\begin{array}{l}\text { Level of adherence } \\
\text { In taken }\end{array}$ \\
\hline \multirow[t]{3}{*}{$\begin{array}{l}\text { Diabetes } \\
\text { duration }\end{array}$} & $\begin{array}{l}\text { Pearson } \\
\text { Correlation }\end{array}$ & 1 & .010 & $-.123^{*}$ & .005 & .035 \\
\hline & Sig. (2-tailed) & & .852 & .020 & .918 & .508 \\
\hline & $\mathrm{N}$ & 360 & 360 & 360 & 360 & 360 \\
\hline \multirow[t]{3}{*}{ Treatment } & $\begin{array}{l}\text { Pearson } \\
\text { Correlation }\end{array}$ & .010 & 1 & .080 & .058 & $.169^{* * *}$ \\
\hline & Sig. (2-tailed) & .852 & & .130 & .274 & .001 \\
\hline & $\mathrm{N}$ & 360 & 360 & 360 & 360 & 360 \\
\hline \multirow[t]{2}{*}{$\begin{array}{l}\text { Health } \\
\text { insurance }\end{array}$} & $\begin{array}{l}\text { Pearson } \\
\text { Correlation }\end{array}$ & $-.123^{*}$ & .080 & 1 & $.202^{* * *}$ & -.026 \\
\hline & Sig. (2-tailed) & .020 & .130 & & .000 & .619 \\
\hline
\end{tabular}


Academic Journal of Research and Scientific Publishing | Vol 3 | Issue 27

Publication Date: 5-7-20. ISSN: 2706-6495

\begin{tabular}{|l|l|c|c|c|c|l|}
\hline & $\mathrm{N}$ & 360 & 360 & 360 & 360 & 360 \\
\hline $\begin{array}{l}\text { Doctor tell } \\
\text { you about } \\
\text { importance } \\
\text { of } \\
\text { adherence }\end{array}$ & $\begin{array}{l}\text { Pearson } \\
\text { Correlation }\end{array}$ & .005 & .058 & $.202^{* *}$ & 1 & -.028 \\
\cline { 2 - 7 } & Sig. (2-tailed) & .918 & .274 & .000 & & .602 \\
\hline $\begin{array}{l}\text { level of } \\
\text { adherence } \\
\text { in taken }\end{array}$ & $\begin{array}{l}\text { Pearson } \\
\text { Correlation }\end{array}$ & .035 & $.169^{* *}$ & -.026 & -.028 & 1 \\
\cline { 2 - 7 } & Sig. (2-tailed) & .508 & .001 & .619 & .602 & 360 \\
\cline { 2 - 7 } & $\mathrm{N}$ & 360 & 360 & 360 & 360 & 360 \\
\hline *. Correlation is significant at the 0.05 level (2-tailed). \\
\hline **. Correlation is significant at the 0.01 level (2-tailed). \\
\hline
\end{tabular}

There is significant Correlation of factors and level of adherence in taken medications only in Treatment types $(\mathrm{P}=0.001)$. But Un significant in Diabetes duration $(\mathrm{P}=0.508)$, health insurance $(\mathrm{P}=0.619)$ and doctor tell you about the Importance of adherence $(\mathrm{P}=0.602)$.

\section{Table (4.8)}

Used multiple regression: Compered between factors with adherence to medications: diabetes duration, treatment, health insurance, and doctor toked about instruction

\begin{tabular}{|c|c|c|c|c|c|c|}
\hline \multirow{2}{*}{\multicolumn{2}{|c|}{ Model }} & \multicolumn{2}{|c|}{$\begin{array}{l}\text { Unstandardized } \\
\text { Coefficients }\end{array}$} & \multirow{2}{*}{$\begin{array}{c}\begin{array}{c}\text { Standardized } \\
\text { Coefficients }\end{array} \\
\text { Beta }\end{array}$} & \multirow[b]{2}{*}{$\mathrm{t}$} & \multirow[b]{2}{*}{ Sig. } \\
\hline & & B & Std. Error & & & \\
\hline \multirow[t]{5}{*}{1} & Adherence & 1.630 & .310 & & 5.264 & .000 \\
\hline & Diabetes duration & .034 & .060 & .030 & .565 & .572 \\
\hline & Treatment & .220 & .067 & .173 & 3.305 & .001 \\
\hline & Have health insurance & -.053 & .095 & -.030 & -.559 & .577 \\
\hline & $\begin{array}{l}\text { Doctor tell you about } \\
\text { importance of adherence }\end{array}$ & -.151 & .255 & -.032 & -.593 & .554 \\
\hline
\end{tabular}


There is significant of treatment types and adherence in taken medications at ( $\mathrm{p}$ value 0.001). By used multiple regression. while un significant in diabetes duration, health insurance, and doctor toked about instruction at sequences (P value 0.572, 0.577, and 0.554).

\section{Table (4.9)}

Compared Correlations of causes with medications adherence:

\begin{tabular}{|c|c|c|c|}
\hline \multicolumn{2}{|c|}{} & $\begin{array}{c}\text { Level of a } \\
\text { adherence in } \\
\text { taken }\end{array}$ & $\begin{array}{c}\text { Causes that make } \\
\text { not adhered }\end{array}$ \\
\hline Level of adherence in taken & $\begin{array}{c}\text { Pearson } \\
\text { Correlation }\end{array}$ & 1 & $.173^{* *}$ \\
\cline { 2 - 4 } & Sig. (2-tailed) & & .001 \\
\cline { 2 - 4 } & $\mathrm{N}$ & 360 & 360 \\
\hline $\begin{array}{c}\text { Causes that make you not } \\
\text { adhered }\end{array}$ & $\begin{array}{c}\text { Pearson } \\
\text { Correlation }\end{array}$ & $.173^{* *}$ & 1 \\
\cline { 2 - 4 } & Sig. (2-tailed) & .001 & 360 \\
\cline { 2 - 4 } & $\mathrm{N}$ & 360 & \\
\hline
\end{tabular}

There is significant of causes and adherence in taken medications at ( $p$ value 0.001 ).

\section{Table (4.9)}

Used multiple regression: Compered between causes with adherence to medications:

\begin{tabular}{|l|l|r|r|r|r|c|}
\hline \multicolumn{2}{|c|}{ ANOVA $^{\text {a }}$} \\
\hline \multicolumn{2}{|l|}{ Model } & $\begin{array}{l}\text { Sum of } \\
\text { Squares }\end{array}$ & \multicolumn{1}{c|}{ Df } & Mean Square & F & Sig. \\
\hline 1 & Regression & 6.591 & 1 & 6.591 & 10.989 & $.001^{\text {b }}$ \\
\cline { 2 - 8 } & Residual & 214.731 & 358 & .600 & & \\
\cline { 2 - 8 } & Total & 221.322 & 359 & & & \\
\hline
\end{tabular}


a. Dependent Variable: level of adherence in taken

b. Predictors: (Constant), causes that make you not adhered

There is significant of causes and adherence in taken medications at ( $p$ value 0.001). By used multiple regression.

\section{Discussion}

This study sought deeper understanding into the adherence to anti-diabetic medications among patients with type two DM attended to Al-Daraga Health Center, Wad Madani Al Kubra, Gezira state 2020. For this discussion, we focus on similarities between ours and other studies in factors affecting medication adherence among people with diabetes.

results showed in socio -demographic characteristics to type II diabetic patients detailed the majority of participants age age more than 50 years about (55\%), that is mean type II diabetes more in advance age than younger, this is agree with study adopt In Sudan,( Hyder Osman et al2019) evaluated the adherence to anti-diabetic medications among type 2 diabetic patients in a Sudanese in Um dorman outpatient clinic. their mean age was (59.62 \pm 9.91$)$ years., also agree with study adopt in Thailand,(Wichuda J 2017) evaluate the medication adherence at an out-patient primary care clinic in Chiang Mai, Thailand.according to gender male more than female by $(12.2 \%)$, this is disagree with study adopt In Ethiopia (Gebre Teklemariam 2019) evaluate adherence to antidiabetic therapy in patients with type 2 diabetes a cross-sectional study insight from Ethiopia In this study 357 study participants were included, of them $54.6 \%$ were female.married more than others about $(58.8 \%)$, the socioeconomic status contributed factors in diabetes mellitus because low income level about 213(59.2\%) I based ot on the patient ability to provide the medications same as in (Thailand Wichuda 2017). urban more than rural by $(53.2 \%)$, in educational level the secondary school were more than others items (39.2\%), also agree with (Gebre Teklemariam 2019) study which show Participants with having at least primary level of education were more likely to adhere to anti-diabetes medication... More than 3/4 from participants resided in urban area, the low education level abundant than higher education, 
about 10 item in working house wife is more than other's (41\%) agree with previous study in Sudan,( Hyder Osman et al 2019) evaluated the adherence to anti-diabetic medications among type 2 diabetic patients in a Sudanese outpatient clinic were housewives. about (63.6\%) of participants had family history of DM. about 93 participant $(25,8 \%)$ diagnosed complications among study, The majority focused on cardiovascular system (88.2\%) which disagree with (Gebre Teklemariam 2019) study show The most common comorbid diseases were hypertension, (52.7\%), followed by dyslipidemia (47.9\%) and ischemic heart disease (10.4\%).

The study show the majority of participants have poor Adherence to management (40.8\%) the most common reason that. said no noticeable improved (45.3\%), Hard to be taken daily (30. $5 \%$ ), Fear of complications (36.6\%) and Lack of knowledge about importance $(24,4 \%)$. same as (Gebre Teklemariam 2019) study show Medication adherence was grouped as non-adherence and adherent. $25 \%$ of participants were reported as non-adherent to their medication. The most common self-reported reason for non-adherence reported by participants was unintentionally forgetting (36.7\%) to take of their medicine, followed by inadequate availability of medications (28.6\%) and lack of affordability (12.6\%). Majority of patient treated by insulin and hard to be taken daily that is agree studies reported that the majority of patients with type 2 diabetes fail to control. (Naqvi et al., 2019)

But the relation between residence and adherence to medication statistically non-significant ( $\mathrm{p}$ value 0.009 ) due to distances

The majority of participant have no complications (74.2\%) and good controlled by using (HbAIc) $(68.6 \%)$ this is due to less duration of DM

$3 / 4$ from participants had health insurance that is enhance patients to get the medications easily. This study will be helpful in providing evidence regarding the importance of adherence should be emphasized and empowered within the diabetic population. 


\section{Conclusion and Recommendations}

\subsection{Conclusion:}

The study revealed that adherence to management was suboptimal among type II diabetic patients because some of patient think there is no noticeable improvement from taking medication, hard to be taken daily and fear of complications. The majority of participant using insulin.The majority of participants had family history. The majority of participant had no complications and had an excellent controlled by using (HbAIc) due to short periods of diabetes mellitus. About 3/4 from participants had health insurance, doctor consultation to patients were excellent, Also there's Statistical connection between socio demographic characteristics to type II diabetic patients as marital status, socioeconomic status, level of education, residence, and occupation.

\subsection{Recommendations:}

- Group discussion to patients for education to word diabetes millets especially long duration and its complications.

- Group discussion to increase knowledge about importance of treatment specially who having insulin and follow up improvement.

- Health education to increase awareness of adhering to diabetes management plan after instructions.

- Further studies should be done to evaluate patients especially who married, low socioeconomic status, low educational level, resided fare away for using diabetes medications.

\section{Acknowledgement}

I would like to express my sincere gratitude to my supervisor Dr. Imadeldin Eljack Suleiman and

Dr Tasabeh Mostafa Eltayeb for the continuous support and for his patience, motivations and immense knowledge.

My sincere thanks also goes to the staff of the Department of Community and Family Medicine in El Gezira University for their support and encouragement, which made it possible for me to complete this research. 
My thankfulness also to AL Daraga Health Center family for their great help throughout data collection.

\section{References}

AlQarni, (2019) AlQarni K, AlQarni EA, Naqvi AA, et al. Assessment of Medication Adherence in Saudi Patients With Type II Diabetes Mellitus in Khobar City, Saudi Arabia. Front Pharmacol.

AlQarni, (2019) World Health Organization (WHO) (2012). Medication adherence. Available at:http://www.who.int/gho/countries/sau.pdf?ua=1(Accessed on 14 July 2019).

Awadalla, (2017) Awadalla H, Noor SK, Elmadhoun WM, Almobarak AO, Elmak NE, Abdelaziz SI, Sulaiman AA, Ahmed MH. Diabetes complications in Sudanese individuals with type 2 diabetes: Overlooked problems in sub-Saharan Africa? Diabetes Metab Syndr. 2017 Dec;11 Suppl 2:S1047-S1051

Basu, (2018) Basu S, Garg S, Sharma N, Singh MM, Garg S. Adherence to selfcare practices, glycemic status and influencing factors in diabetes patients in a tertiary care hospital in Delhi. World J Diabetes.

Care, (2014) American Diabetes Association. Diagnosis and classification of diabetes mellitus. Diabetes Care. 2014; 37 Suppl 1:S81-S90.

Forouhi, (2014) Forouhi NG, Wareham NJ. Epidemiology of diabetes. Medicine (Abingdon). 2014;42(12):698-702.

Garcia-Perez, (2013) García-Pérez LE, Alvarez M, Dilla T, Gil-Guillén V, OrozcoBeltrán D. Adherence to therapies in patients with type 2 diabetes. Diabetes Ther. 2013;4(2):175-194.

Mirghani, (2019) Mirghani HO. An evaluation of adherence to anti-diabetic medications among type 2 diabetic patients in a Sudanese outpatient clinic. Pan Afr Med J. 2019;34:34.

Naqvi, (2019) Naqvi A. A., AlShayban D. M., Ghori S. A., Mahmoud M. A., Haseeb A., Faidah H. S., et al. General medication adherence scale in Saudi patients with chronic diseases. Front. Pharmacol 2019. 10, 633. 
Naqvi, (2019) Naqvi A. A., Hassali M. A., Aftab M. T., Nadir M. N. (2019. a). A qualitative study investigating perceived barriers to medication adherence in patients with chronic illness in Karachi, Pakistan. J.

Omar, (2019) Omar SM, Musa IR, ElSouli A, Adam I. Prevalence, risk factors, and glycaemic control of type two diabetes mellitus in eastern Sudan: a community-based study. Ther Adv Endocrinol Metab. 2019;10:2042018819860071. Published

Osterberg, (2005) Osterberg L., Blaschke T. (2005). Adherence to medication. N. Engl. J. Med. 353, 487-497. 10.1056/NEJMra050100

Yusuff, (2008) Yusuff KB, Obe O, Joseph BY. Adherence to anti-diabetic drug therapy and self management practices among type-2 diabetics in Nigeria. Pharm World Sci. 2008 Dec;30(6):876-83.

Zheng, (2018) Zheng Y, Ley SH, Hu FB. Global aetiology and epidemiology of type 2 diabetes mellitus and its complications. Nat Rev Endocrinol. 2018 Feb;14(2):88-98 2018;9(5):72-79. 2019 Jun 27. doi:10.1177/2042018819860071

Gebre Teklemariam (2019) Demoz,corresponding author1 Shishay Wahdey,2 Degena Bahrey,3 Halefom Kahsay,4 Gebremariam Woldu,1 Yirga Legesse Niriayo,5 and Andrew Collier. Predictors of poor adherence to antidiabetic therapy in patients with type 2 diabetes: a cross-sectional study insight from Ethiopia.Published online 2020 jul 16,doi:10.1186/s13098020-00567-7

Wichuda J (2017) Jiraporncharoen, W., Pinyopornpanish, K., Junjom, K. et al. Exploring perceptions, attitudes and beliefs of Thai patients with type 2 diabetes mellitus as they relate to medication adherence at an out-patient primary care clinic in Chiang Mai, Thailand.

Copyright ( 2021 Dr. Rasha Kamal Bashir, Dr. Imad Eldin Eljack Ahmed, Dr. Tasabeh Mustafa Eltayb Ali, AJRSP. This is an open-access article distributed under the terms of the Creative Commons Attribution License (CC BY NC).

Doi: $\underline{\text { doi.org/10.52132/Ajrsp.e.2021.271 }}$ 